\title{
Fertility, GDP and Average Real Wage in Cuba
}

Excerpted by the author, translated and reprinted with permission from Novedades en Población. No. 7, Jul-Dec 2014;79-92.

Original available from: $h$ ttp://www.novpob.uh.cu/index.php/rnp/article/view/219

\section{Juan Carlos Albizu-Campos PhD}

\begin{abstract}
Cuba's accelerated trend to lower fertility and consequent contraction of population reproductive capacity have now become concerns for various social and political actors, including, of course, Cuban demographers, who have been sounding the alarm for more than three decades. The most striking characteristic of Cuba's fertility transition is undoubtedly its abrupt onset, rapidity, and the fact that it took place in the absence of accompanying economic development. Hence
\end{abstract}

\section{INTRODUCTION}

The reduction of fertility levels [in Cuba], at least from 1990 until now, has become an object of increasing attention by demographers, researchers and actors from different sectors of society. . . It is well known that the Cuban population's reproductive capacity has undergone an accelerated historic decline, leading to the total annual fertility rate falling below replacement level in less than half a century. This transition from high to low average number of children per woman, has been well documented internationally, ... with attention to various socioeconomic factors operating at different times.

Thus, many populations are below replacement level and are in the so-called second demographic transition.[1] Having completed the first transition towards the end of 20th century, [in such populations] families' needs to make the most of limited resources available during the 1990s (marked by an acute economic crisis) led to couples delaying childbearing and reducing family size in response to hard economic times, and to postponement of new investments in human capital [represented by new children]. This seems to have become commonplace. No Latin American country that has completed the transition has returned to the pattern of larger family size under adverse economic conditions.[2] Even some populations relatively lacking in economic development, have already reported sustained population decreases,[3] their fertility descending to historical minimum levels,[4] well below projections to 2030.[5]

\section{EVIDENCE AND THEORY}

So the question arises: How was this possible? When substantial economic recovery occurs, one would logically expect a return to precrisis fertility levels, as some authors have reported.[6] But the decision whether or not to have a child remains tied to economic, social, psychological and aspirational motivations already reflected in population reproductive norms[7] that assume a small family is economically more efficient, whether or not there is economic crisis.

Other authors had started to indicate a possible [negative] effect of adverse economic conditions on fertility in recent years.[8] . . . But one detail seems to have been overlooked. Is this pattern not completely opposite to the relationship between fertility and per the current debate focusing on the roles of the various determinants that led to the transition, and especially of economic factors at different stages, particularly in conditions of heightened population vulnerability during economic crises. This article provides elements to help fill gaps in knowledge of the fertility-development relationship today.

KEYWORDS Fertility, fertility determinants, below replacement fertility, demographic transition, population transition, development, population dynamics, Malthusianism, Cuba

capita gross domestic product (GDP) described by demographic theory until now? Is there not an inverse relationship between fertility and development, and consequently, between fertility and GDP per capita? And even though it has been shown that contemporary fertility transitions have begun at increasingly lower development thresholds, do we not continue to see this inverse relationship?[9]. . .

Gathering information for 69 countries, at 5-year intervals from 1960 to 1985, on socioeconomic indicators such as real per capita GDP, life expectancy at birth, literacy and total fertility rate, Bongaarts and Watkins (1996) reported some crucial findings concerning the relationship between these indicators.[10] Foremost is the confirmation of a significant negative correlation between fertility and development as measured by the human development index (HDI).

Fertility decreases as development progresses. In addition, it seems that fertility remains high at an $\mathrm{HDI}$ of $\leq 0.4$, but once it exceeds a threshold of 0.6 , the total fertility rate in almost all countries begins a sustained transition to low levels. This decline is accelerated once HDI reaches 0.7 , accounting for a nonlinear relationship between the two indicators. But the most remarkable thing is that, while a wide range of fertility levels is observed for fixed HDI values, fertility changes are only partly attributable to development level; there is a sizable group of other factors, whose action is indispensable to fully explain changes in total fertility rate, complementing the part explained by economic progress.

This accounts for another essential finding: the relationship between fertility and development indicators has changed over time. Contemporary transitions have started at increasingly lower development thresholds, indicating the increasing importance of those other factors. . . Thus, it is possible to assert two things. First, there are limitations to development's effect on fertility decline. Second, despite these limitations, development explains more than two fifths of fertility change. . .

However, this model seems to assume steady development progress. What happens when acute-phase economic crises take place? Several authors contend that a crisis causes populations to become aware of the fact that their demographic behaviors, notably reproductive ones, are no longer suitable to the new eco- 
nomic and social scenarios imposed on society. This awareness is even stronger and more quickly acquired by individuals living in health, social and cultural contexts marked by diffusion of ideals and demographic practices favoring decreased fertility.[11] . . .

\section{GDP, WAGE AND FERTILITY}

. . Some features of economic and demographic indicator dynamics are remarkable for their contrast with what is commonly supposed. In the first place, recently and in certain settings, a positive association is beginning to be noticed between them, at least during the last decade of the previous century. . .

In Cuba, the sharp decline (35\%) in per capita GDP during the first half of the 1990s dragged down the total fertility rate, which declined by more than one fifth, meaning a loss of 0.39 children per woman between 1989 and 1996 and representing a cumulative deficit of 44,615 births in the same period.[12] This shows that families adopted fertility-restriction measures to deal with the crisis. After 1996, trends for both indicators, especially per capita GDP, began to recover. After the late twentieth century, changes in fertility patterns disrupted the inverse relationship between fertility and GDP, so that the economic indicator was only partially able to explain the dynamics of the demographic indicator.

Two key elements are notable in this case: although its influence may be limited, economic growth is an underlying force that explains not only onset of the fertility transition, but also subsequent changes in average number of children per woman and the pace at which these changes occur, accounting for just under two thirds of changes in total fertility rate. . Second, the direction of the relationship changed and the two indicators were no longer inversely correlated. A positive linear function slope showed that fertility followed the direction of changes in per capita GDP, in contrast with what is described in various theoretical frameworks.

However, part of per capita GDP's limitations for predicting fertility change resides in its very nature as a macroeconomic indicator. . . If we want an indicator that better reflects a population's standard of living, we need to go to the individual level to find information that accounts for individuals' actual daily capacity to meet their needs (both basic and other) in a given context. We need to seek indicators that do not commonly appear in current publications, but are known through specific studies conducted for this purpose. . .

One such indicator is average real monthly wage, which expresses living standards and services available to workers and indicates the amount of consumer goods and services they can buy with their nominal wages (in money). Its magnitude is determined by the nominal wage (money received by workers for work done) and by prices of consumer goods and services (indicated by the consumer price index, which simply collates prices and temporal price variations of a group of products regularly purchased by consumers). At the individual level, where reproductive patterns that later characterize a population at macro level are established, average real monthly wage is a much more robust predictor than GDP per capita, and its relation to fertility has greater capacity to explain changes in average number of children per woman, at least in individual cases and for certain periods.
In Cuba, both indicators fell simultaneously between 1989 and 1993 , the decline in real monthly average wage being somewhat more pronounced. Thereafter, a recovery process occurred with quite different dynamics. First, a sequence between initial acceleration and subsequent recovery slowdown, later moving into an asymptotic trend that continues to date.

The sharp fall in total fertility rate extended until 1996, with an oscillation in 1995 . Its recovery began by 1997 , delayed by two years with respect to real average monthly wage. The trend continued thereafter, oscillating between gradual declines and slow increases. .. In this context, fertility followed the marked decline in the population's ability to meet their needs of any kind. All this happened despite substantial efforts during the period to sustain the population's quality of life.

To date there has been a pronounced recovery in nominal average monthly wage, but the pattern for real average monthly wage has been similar to that of per capita GDP, reaching its nadir in 1993.[13] Measures to increase nominal wage were neutralized by an explosive rise in prices of all products. As Vidal noted, while nominal average wage almost doubled during the period, prices increased more than eightfold.[14] . . . This meant the population's purchasing power fell by more than four times.[15] Thus, the decline and subsequent stagnation of progress in the population's purchasing power turned real average monthly wage into a robust predictor of fertility in Cuba.

In effect, the relationship between fertility and population standard of living became the opposite of what was predicted by classical population theory. The correlation stopped being inverse and became direct, with fertility decreasing as real average monthly wage decreased. Second, the explanatory ability of changes in real wages on changes in total fertility rate is significantly higher than that observed for GDP and higher than observed in other contexts. And third, real wage is a robust predictor of the pattern of average number of children per woman (confirmed by all [statistical] tests performed).

Therefore, it is possible to assert that approximately four fifths $\left(R^{2}\right.$ $=0.7868$ ) of changes in fertility level were explained by variations in real average monthly wage, reduction of which led to decreased total fertility, making real average monthly wage a powerful underlying force shaping population reproductive patterns during the period studied.

,.. How should we interpret what happened during the period? It would seem that during the acute phases of the crisis, increased direct costs of motherhood (although not of medical services), declining economic opportunities for adults, job losses, and declining population capacity of the population to meet needs, among other factors, reinforced a cultural trend to small families in Cuba. Combined with widespread use of contraception and access to abortion, they led to a new fertility pattern with two distinctive features: increased average age of motherhood and reduction in the average number of children compared to the previous decade.

In this case of a population that had completed its transition in the late 1980s, the need for families to make the most of limited resources available during the decade led to couples delaying childbearing and reducing the number of children in response to economic conditions. Between 1989 and 1996, the birth deficit 
was very close to 45,000 , and by 2006 , it was 73,568 , compared to the late 1980s. . .

It could have reasonably been expected that fertility would recover and return to prior levels, once the years of severest economic stress were over. . . However, the opposite happened, pointing to the presence of other social transformation processes, whose ultimate results were a reconfiguration of Cuba's reproductive patterns: a) postponement of first marriage, b) postponement of children, and c) reduction in number of children.

\section{VULNERABILITY AND MALTHUSIANISM}

In a context of severe deterioration of living conditions during the early 1990s, families in general, especially the most disadvantaged, perceived the birth of a new child as an immediate risk to the survival of the rest of the family. The number of children per woman decreased due to two factors: postponement of marital unions, especially the first, and the widespread practice of combining contraception methods for fertility postponement and termination. . .

The direction of the relationship between fertility and economic development was reversed, adopting a positive correlation, and fertility dynamics followed the trend set by economic indicators, mainly those close to family life, notably, real wage. The proportion of the population affected by contraction of individual and family standard of living was large enough to be reflected at the macro level of total annual fertility rate, thus showing change in the composition of Cuba's reproductive system. Prolongation of this situation meant that this change, which could have been temporary, gave way to a new reproductive norm, which was transmitted across generations and especially impacted teenagers who were starting or were about to start their reproductive life. . .

Faced with increasing and spreading poverty, families perceived an increase in number of children as a possible trigger for vulnerability, and identified the birth of additional children as a risk to the rest of the family's immediate survival, considering the demonstrated [negative] effect of [a] high demographic burden as a determinant of inefficient family economic performance under crisis conditions [small families do better during economic crises].

Thus, family reproductive strategies were rearranged on the basis of three elements:

- Postponement of marital unions, essentially the first ...

- Contraception to postpone fertility ...

- Contraception to end fertility (sterilization, mainly female). . .

\section{POSTPONEMENT OF FIRST MARRIAGE}

The negative effects of limiting marital unions on number of births and, therefore, on population growth capacity, have been widely documented in theory. Reducing the time women are exposed to risk of pregnancy and extending the interval between marriage and first birth result in overall parity reduction. . .

Cuba has both the youngest average age at marriage in Latin America and the lowest fertility, indicating important changes in couple relationships,[16] marked by high rates of divorce and voluntary separation, a pattern much different from what would be expected [from demographic theory and international experience] $\ldots$
Patterns of formation, dissolution and reconstitution of family structures underwent a process of gradual lowering of age at first marital union between the 1970s and 1980s, combined with an average number of children per woman below replacement level, a departure from the general patterns and theory of demographic transition. . . This behavior is also linked to more common-law relationships. . .

However, after this unexpected decline, average age at first marital union underwent a rapid increase (at an estimated rate of three months per year) in the acute phase of the economic crisis, reaching more than 20 years. Marriage was long postponed, replaced by premarital cohabitation and frequent resort to voluntary dissolution of the union.[17] . . Average age at first marriage is now well above 21 years, very close to 22 , an age at which marriage starts to be considered late [by demographers].[18] . . .

\section{CONTRACEPTION TO POSTPONE FERTILITY}

Several studies have documented the high population prevalence of contraception use [in Cuba] at different times,[19] especially when such prevalence is considered in the framework of the proximate determinants model of fertility, which is widely used in international demographics.

All authors agree that contraception [in Cuba] has two main features: a) high and increasing coverage, and b) widespread use of modern contraceptive methods. . . This is no coincidence, given that comprehensive family planning services have been offered since the 1970s, . . . becoming strengthened and specialized over time with creation of a national infrastructure having on-site access and trained human resources.[20]

However, despite increased contraception prevalence from the 1990s to the present, qualitative research highlights that from an individual perspective, knowledge of contraception methods, their operation and action in the body, is more formal than real.[21] In many cases, use is discontinuous and frequently interrupted, . . . despite extensive information available that does not yet seem to have found the right channels of social interaction to establish itself as fundamental knowledge and thus modulate population reproductive behavior...

At least in recent years, there is a clear trend towards increased pregnancy interruption [abortion or menstrual regulation] in Cuba . . . Two key features are present: a) since the 1990s, the total rate of interruptions exceeds the total fertility rate, something not seen up to the previous decade, and b) there has been a gradual, but steady, trend of increased recourse to pregnancy interruption (whether menstrual regulation or abortion). Thus, the average number of children born alive is exceeded by the average number of interruptions per woman. . .

Pregnancy continuation in Cuba does not appear to be rationalized in terms of the achievement of a certain [traditional] reproductive ideal, which continues to be two children. This ideal does not seem to play a significant role in the decision whether or not to continue pregnancy once it has occurred. . . Having a child or not is a decision fundamentally rooted, first, in economic motivations, social conditions and personal aspirations,[22] interacting with intergenerationally transmitted notions that determine not only the ideal of children, but also the "culture" of abortion accompanied by 
unpreparedness for couple relationships and family life, in a setting where reproductive events seem to echo past experiences, transmitted from mothers to daughters.[23]

\section{CONTRACEPTION TO TERMINATE FERTILITY}

... In fertility surveys, $30 \%$ of [Cuban] women who reported using contraceptive methods had been sterilized, meaning that approximately one in three women who used contraception had done so to terminate their reproductive capacity. They represented $18 \%$ of all women aged $15-49$ years at time data collection.

On the other hand, this level of sterilization means that for every 100 women at risk (not pregnant at the time of the survey, married or in a consensual union, and not sterilized), 27 had decided to end their reproductive capacity, a clear increase in the prevalence of sterilization, which reached as high as $20 \%$ of all women between 12 and 49 years old. And it is notable that the years in which this proportion was highest corresponded to those in which the level of pregnancy interruption was also lowest. It is plausible that this counterpoint between abortion and female sterilization reflects the combined action of both forms of contraception (postponement and termination of fertility), which is clearly behind the nonrecovery of fertility levels seen before the acute phase of the economic crisis. . .

To date we have not sufficiently addressed questions about what we can expect from prolonged low fertility, and whether recently observed changes in the tempo of motherhood will play a role in possibly increasing total annual fertility. . . Nevertheless, current international experience has been pointing to substantial changes in fertility schedules for years, their impact on populations that already had low fertility and how it led them to dramatically lower levels, highlighting the real possibility of population shrinkage and aging.[24,25] Although there have been examples of how interrupting the depressor effect of postponement has led eventually to increases in fertility, it remains unclear whether such fertility increases will have a lasting effect on recovery of the reproductive capacity of populations where low fertility has become, for more than three decades, a culturally endorsed model. . .

In any case, what has been documented is that, in other contexts, elimination of the contracting effect of fertility postponement certainly does not produce any change in hypothetical achievement of the replacement level. . . The baby boom appears to have been no more than a change of calendar for having children, rather than a change in the reproductive pattern of fertility in the generation that gave rise to it. . . Hence, another baby boom is unlikely, and economic circumstances, however adverse, will not change reproduction patterns attained by a population once it completes the demographic transition.[26]

\section{LESSONS FOR THE FUTURE}

Considering that an effective decrease has already been recorded in populations with prolonged periods of very low fertility, and that ... new historical minimum levels have been reached, then it is relevant to ask, what will happen to the population's reproductive capacity, at least for the short term? . . .

It is plausible to assume. . . that recent upward trends in average age of fertility will continue, at least in the near future, and will reach just over 28 years, a pattern found in various other con- texts with reproductive (although not economic) dynamics similar to Cuba's.

In a scenario of $50 \%$ recovery of postponement, average age of fertility would continue to increase steadily and would again account for at least fertility stagnation in the short term, considering what this would imply in number of children potentially lost by postponing motherhood, although this would be less than in a scenario of nonrecovery. Full recovery of postponement would mean eliminating the motherhood postponement lag for younger cohorts of women, who would enter fertile life with a lowered of average age of fertility. . .

Whatever the scenario regarding postponement, and even if younger cohorts of fertile women were to return to an earlier fertility schedule, total fertility rate would not return to replacement level, at least for the intermediate future. On the contrary, in a scenario of nonrecovery of postponement, the most plausible result, if recent trends continue in the near future, is a historical low in total fertility rate. .

It should be noted that little can be expected in terms of recovery of reproductive potential in a population with very low fertility over long periods of time. At least in the short term, fertility will continue to fluctuate with a declining trend. And this is only the consolidation of a reproductive norm, culturally diffused by its own example, of reduced numbers of offspring. The process will be driven even by those women who, despite having earlier fecundity, have adopted childbearing postponement as the fundamental reproductive element of their life strategies, and in whom importance of the role of motherhood is not yet clear.

\section{Thus, is low fertility a temporary phenomenon in Cuba?}

... In any case, fertility decline in recent years suggests a certain demographic fragility of the population, with changes in natural increase: the accumulated loss of live births, showing that families adopted restrictive fertility measures to deal with the crisis. . .

One might then ask, is a decrease in fertility always a sign of progress in the field of reproduction? The answer would be yes, if such a decrease were the result of greater exercise of reproductive rights, an increase in supply and quality of means for regulating family size, and improvements in the family planning process, in which use of contraception became increasingly effective. However, it can also be a clear sign of reversal after long periods of fertility below replacement level, and when lack of progress or stagnation of quality of life exceeds a threshold such that couples indefinitely postpone the achievement of their reproductive hopes. . .

To review five outstanding features that have been identified:

1. After the accelerated processes of fertility decline and homogenization that led to the end of the first transition, two new features seem to characterize today's reproductive behavior: a) establishment of a clear pattern of postponed motherhood and b) increasing contribution of fertility at later reproductive ages.

2. A notable increase in first-order fertility in later life, at age 30 years or more, as result of delayed motherhood associated with postponement of first pregnancy. . .

3. Average age at first marital union has increased substantially and is close to 22 years, commonly considered a pattern of late marriage. . 
4. Motherhood postponement affects all women, regardless of socioeconomic status, being more pronounced in rural women, those living common law, less educated or in more precarious situations. These women are on average younger than their counterparts, and have lower average age of fertility.

5. Sustained increases in use of voluntary pregnancy termination, combined with a high prevalence of female sterilization, has strengthened the contraction effect of very high contraceptive coverage and this has led to a new decline in fertility.

The appearance of these features is remarkable for the short period of time in which they started to become evident in combination. And all this in a context of economic crisis. The dual effect of this crisis is summarized as, on one hand, an abrupt and intense outburst in the early years, and on the other, the subsequent persistence of resulting socioeconomic dislocations. . .

It would be simplistic to attribute all these changes exclusively to [Cuba's economic] crisis. However, we should also ask whether the crisis was neutral in demographic terms, whether it changed anything in the fact that the fertility decline was already included in Cuba's cultural changes, or whether, on the contrary, it accelerated the gestation and development of this phenomenon, which has been called the "Malthusianism of poverty,"[27] as opposed to that other Malthusianism of wealth. It would be more generalizable if it were called the "Malthusianism of vulnerability," because as the Cuban case shows, it is not necessary to be poor to conceive a reproductive strategy for family survival in which postponement and reduction of family size are two sides of one coin. . .

If, indeed, the economic crisis and subsequent adjustment policies influenced demographic dynamics, this influence was mediated by a deteriorated standard of living. . . Thus, families with a tradition of small numbers of children perceived the birth of additional children as an insurmountable risk to the immediate survival of their members,[28] and couples' reproductive strategies were structured on postponement of achieving the ideal number of children or termination of reproductive capacity through female sterilization. Prolongation of this phenomenon then led to formation of new reproductive norms.

Thus, it is also plausible to suppose that this reproductive behavior would become the gateway to the second demographic transition, in the same way it acted as one of the forms of onset and development of the first demographic transition,[29] given the diffusion effects, through social interaction, shown in the most affected and vulnerable population groups. . .

Any recovery in fertility levels can only be expected from a decisive improvement in population living standards and a return to stable and lasting economic conditions in which recovered confidence in future security becomes a key component of people's life strategies. And, one might even ask, does Cuba need to return to higher fertility levels than are seen at present? $-1 /$ -

\section{REFERENCES}

1. Rodríguez Gómez, G., 2006, "La fecundidad cubana a partir de 1990. Las perspectivas sociales e individuales". Tesis presentada en opción al grado de Doctor en Ciencias Económicas. Centro de Estudios Demográficos - Universidad de La Habana. Inédito, pp. 30-38.

2. Albizu-Campos E., J.C., 2003, "Las estrategias de vida, los hijos y la ley del valor", CD-ROM Novedades de población (ISBN 959-7005-31$X)$. Centro de Estudios Demográficos - Universidad de La Habana. La Habana, febrero 2004, p. 26.

3. Trinquete Díaz, D. E., 2007, "Población. Comenzó la cuenta atrás”, Bohemia, Año 99, No.1. La Habana, enero, 2007, p. 40.

4. CEPDE-ONE, 2007, "Anuario Demográfico de Cuba, 2006". Oficina Nacional de Estadísticas, Ministerio de Economía y Planificación. La Habana, 2007. Tabla II.4, p. 42

5. Rodríguez Gómez, G. y Albizu-Campos E., J.C., 2007, “¿Es la baja fecundidad un fenómeno temporal en Cuba?". Memorias del Taller Internacional "América Latina y el Caribe: Retos Sociodemográficos en el Tercer Milenio". ISBN 959-282-042-2. Centro de Estudios Demográficos - Universidad de La Habana. La Habana, febrero, pp. 22-23.

6. Lesthaeghe R. y Jolly C., 1994, "The Start of the Sub-Saharan Fertility Transitions : Some Answers and Many Questions", in Campbell K. L. et Wood J. W., Human Reproductive Ecology - Interactions of Environment, Fertility and Behaviour, Annals of the New York Academy of Sciences, vol. 709, New York, pp. 379-395.

7. Idem nota 1, p. 124

8. Idem nota 2, p. 25.

9. Bongaarts, J. y Watkins, S. C., 1996, "Social interactions and contemporary fertility transitions" en Population and Development Review 22(4): pp. 639-682.

10. Idem nota 9, pp. 642-645.
11. Vimard, P., Fassassi, R. y Talnan, E., 2001, "Le debut de la transition de la fécondité en Afrique Subsaharienne. Un bilan autour des exemples du Kenya, du Ghana et de la Côte d'Ivoire" en XXIV Congrés Général de la Population - S84 Les faces multiples de la démographie africaine. Salvador-Brésil: Union Internacional pour l'Etude Scientific de la Population: pp 1-31, p. 27

12. Pérez Villanueva, O.E., 2006, "La situación actual de la economía cubana y sus retos futuros", en Pérez Villanueva, O.E. (compilador), Reflexiones sobre Economía Cubana. 2da. Edición. Editorial de Ciencias Sociales, La Habana, ISBN 959-06-0839-6, pp. 1-40, p. 1.

13. Idem nota 1, p. 8.

14. Vidal Alejandro, P., 2006, "Estabilidad, desdolarización y política monetaria en Cuba”, en Pérez Villanueva, O.E. (compilador), Reflexiones sobre Economía Cubana. 2da. Edición. Editorial de Ciencias Sociales, La Habana, ISBN 959-060839-6, pp. 41-60, p.45.

15. Nova González, A, 2006, "El mercado interno de los alimentos", en Pérez Villanueva, O.E. (compilador), Reflexiones sobre Economía Cubana. 2da. Edición. Editorial de Ciencias Sociales, La Habana, ISBN 959-06-0839-6, pp. 215-239, p.236.

16. Cosío-Zavala, M. E., 1999, "Les deux modèles de transitions démographiques en Amérique Latine et les inégalités sociales: le malthusianisme de pauvreté", en Seminario General de la Red de Estudios de Población ALFAPOP, "Temas de población latinoamericanos". Centre d'Estudis Demogràfics. Barcelona, Bellaterra, febrero 1999, p.7

17. Ibidem nota 1, p. 34

18. Ibidem nota 14 p. 7.

19. Hollerbach, P. y Díaz-Briquets, S., 1983, "Fertility determinants in Cuba". Commitee on Population and Demography. Report No. 26. Washington.Álvarez V., L., 1987, "Determinantes próximos de la fecundidad en Cuba.
Modelo de Bongaarts", en Revista Cubana de Administración de Salud. Volumen 13, No. 4. La Habana. Catasús C., S. y Alfonso F., J. C., 1990, "La transición de la fecundidad en Cuba". Centro de Estudios Demográficos - Instituto de Investigaciones Estadísticas. La Habana. Albizu-Campos E., J. C., 1991, "Determinantes de la fecundidad en Cuba y sus regiones, 1987". Centro de Estudios Demográficos - Instituto de Investigaciones Estadísticas. La Habana. González, H., 1992, "Determinantes próximos de la fecundidad regional y por tipo de lugar de residencia". Instituto de Investigaciones Estadísticas. La Habana, (inédito).

20. Gran Álvarez, M. A., 2005, "Interrupción voluntaria de embarazo y anticoncepción. Dos métodos de regulación de la fecundidad. Cuba 19952000". Tesis doctoral. Temas de Estadísticas de Salud. Ministerio de Salud Pública. ISSN 17277884. La Habana.

21. Rodríguez Gómez, G., 2006, "La fecundidad cubana a partir de 1990. Las perspectivas sociales e individuales". Tesis presentada en opción al grado de Doctor en Ciencias Económicas. Centro de Estudios Demográficos - Universidad de La Habana. Inédito.

22. Gran Álvarez, M. A., 2005, "Interrupción voluntaria de embarazo y anticoncepción. Dos métodos de regulación de la fecundidad. Cuba 19952000". Tesis doctoral. Temas de Estadísticas de Salud. Ministerio de Salud Pública. ISSN 17277884. La Habana, 122ppp. 29-30.

23. Idem nota 1, p. 119.

24. Ibidem nota 1, p. 124

25. CEDEM-ONE-MINSAP, 1995, "Cuba. Transición de la fecundidad. Cambio social y conducta reproductiva". UNICEF-FNUAP. La Habana, p. 35.pp. 87-88.

26. Bongaarts, J. and Feeney, G., 1998. "On the quantum and tempo of fertility", Population and Development Review 24(2): 271-291, p. 285. 


\section{Reprint}

27. Lesthaeghe, R. and Willems, P., 1999. "Is low fertility a temporary phenomenon in the European Union?", Population and Development Review 25(2): 211-228, p. 212

28. Albizu-Campos E., J.C., 2003, "Las estrategias de vida, los hijos y la ley del valor", CD-ROM Novedades de población (ISBN 959-7005-31-X).

Centro de Estudios Demográficos - Universidad de La Habana. La Habana, febrero 2004, pp 27-28.
29. Cosio-Zavala, M. E., 1994. "Changements de la fécondité au Mexique et politiques de fécondité". Paris, L'Harmattan, $255 \mathrm{p}$.

30. Boserup E 1985, "Economic and demographic interrelations in sub-saharan Africa", Population and Development Review, 11, n 3, p. 383-397.

31. Cosío-Zavala M. E., 2000, "Singularités et modalités des transitions de la fécondité en Amérique Latine", en Pilon, M. y Guillaume, A. (eds.), Maîtrise de la fécondité et planification familiale au
Sud. Collection Colloques et Séminaires, Éditions IRD, Paris, 2000, pp. 21-33.

\section{THE AUTHOR}

Juan Carlos Albizu-Campos Espiñeira (albizu@cedem.uh.cu), economist and demographer. Full professor, University of Havana Center for Demographic Studies, Havana, Cuba. 